Original Article

\title{
COMPARISON OF ANTIBACTERIAL ACTIVITY OF EXTRACT OF PROSOPIS JULIFLORA SEEDS AGAINST AEROBIC AND ANAEROBIC BACTERIA
}

\author{
A. AMRITHA ${ }^{1 *}$, G. BHUVANESHWARI ${ }^{2}$, M. MALAVIKA ${ }^{3}$, ROSY VENNILA ${ }^{4}$ \\ ${ }^{1}$ Saveetha Medical College and Hospital, Kuthambakam, Chennai600124, Tamilnadu, ${ }^{2,3,4}$ Department of Microbiology, Saveetha Medical \\ College and Hospital, Kuthambakam, Chennai 600124, Tamilnadu \\ Email: amritha.ashok123@gmail.com \\ Received: 15 Sep 2020, Revised and Accepted: 17 Nov 2020
}

\begin{abstract}
Objective: To compare the antibacterial activity of prosopisjuliflora seed extract against aerobic and anaerobic bacteria.

Methods: A cross sectional study was conducted for 6 mo in the clinical microbiology laboratory of SMCH. Agar cup diffusion technique is used to isolate the strains of Clostridium perfringens ATCC 3624, Staphylococcus aureus ATCC 25923 and Escherechiacoli ATCC 25922. The prosopisjulifloraseeds are collected from the saveetha medical college.
\end{abstract}

Results: By performing the research with proper guidance it is observed that all the three bacterias-Staphylococcus aureus, Escherechia coli, Clostridium perfringens showed sensitivity to prosopisjulifloraseed extract.

Conclusion: Due to its vast antibacterial activity it can be used along with other antibiotics to increase its efficacy. This is used for the treatment of infectious diseases.

Keywords: Antibacterial activity, Prosopisjuliflora, Staphylococcus aureus, Escherechia coli, Clostridium perfringens,Agar cup diffusion technique

(C) 2021 The Authors. Published by Innovare Academic Sciences Pvt Ltd. This is an open access article under the CC BY license (https://creativecommons.org/licenses/by/4.0/) DOI: https://dx.doi.org/10.22159/ijcpr.2021v13i1.40802. Journal homepage: https://innovareacademics.in/journals/index.php/ijcpr

\section{INTRODUCTION}

Scientists have shown that the traditional medicine used in parts of Africa and Asia could help to treat many diseases. Medicinal plants are used to treat many human diseases because they have therapeutic values and some can also be used for prophylactic purposes. The medicinal value of the plants lies in some chemical substances that produce definite physiological action on human and animal body. They are the precursor of synthesis of certain drugs. As multiple drug resistance was developed against many organisms due to the use of commercial antibiotic drugs use of either new synthetic or natural antimicrobial drugs are necessary to combat diseases $[1,2]$.

Prosopisjuliflora is one of the most widespread species of genus prosopis. Genus prosopis includes 44 species that are mainly distributed in regions of Asia, Africa, and America. It is the major source of fuel and fodder. It is a multipurpose dry land tree or shrub. It has antifungal, antiseptic, anticancer, antioxidant, antimicrobial activity. It is used to treat eye conditions, open wounds, and dermatological ailments. The aim of the present study is the invitro investigation of the antibacterial activity of prosopisjuliflora seeds against some aerobic and anaerobic bacteria $[3,4]$.

For this investigation aerobic gram negative bacteria Escherichia coli ATCC 25922, aerobic gram positive bacteria Staphylococcus aureus ATCC 25923 and anaerobic gram positive bacteria clostridium perfringens are used.

Escherichia coli is present in the normal intestinal flora. Most of them are harmless and even keep the digestive tract healthy. But some strains can cause diarrhoea on eating contaminated food or drink. Staphylococcus aureus frequently found in the upper respiratory tract and on the skin. Some strains cause skin infections, respiratory infections and food poisoning. Clostridiumperfringens are strictly anaerobe they are found in the environmental source as well in the intestines of humans and animals. They cause food borne illness. On extreme they also cause gas gangrene. It is also caused by group Astaphylococcus aureus species. The relation between all three bacteria is that they all cause food poisoning. Hence the aim of this research is to determine the antibacterial activity of prosopisjuliflora against all these three bacteria [5-8].

\section{MATERIALS AND METHODS}

\section{Extract}

Prosopisjulifloraseeds were collected from theProsopisjuliflora plant in Saveetha Medical College, Chennai.The seeds were washed and dried in paper towel partially. For proper drying it was kept in an oven at 60degree Celsius. The seeds were then crushed to fine powder using a mixed grinder. A suspension was then formed by mixing it in a distilled water after $3 \mathrm{~h}$. The extract was filtered using a filter paper. The organic phase was separated from aqueous phase using a separatory funnel.

\section{Microorganisms}

The bacterial test organisms Staphylococcus aureus ATCC 25923, Escherichia coli ATCC 25922 and Clostridium perfringens ATCC 3624 are obtained from the microbiology department

\section{Antimicrobial susceptibility testing}

Agar cup diffusion technique

It is the most sensitive antibiotic susceptibility testing method also called as Kirby-Bauer method. The use of it is to find the susceptibility of bacteria against antibiotics. Muller hinton agar is used for this technique as it gives satisfactory growth result for many organisms [9].

\section{Principle}

The antibiotic impregnated disc is placed over a previously inoculated agar medium with test bacterium. The bacterium picks up moisture and the antibiotic diffuse radially outwards on the agar medium. This produces a high concentration gradient of antibiotic at the edges of the disk so the concentration decreases as it diffuse radially outwards. This creates a zone of inhibition around the disk, where the bacterium couldn't grow, if the antibiotic is effective against the bacterium [9].

\section{Methodology}

Preparation

Two NA plates 1 and 2 were taken and dried. Staphylococcus aureus and Escherichia coli specimens were inoculated in peptone water in 
separate test tubes. It is incubated for 20 min under 37 degrees Celsius. After incubation the two organisms undergo lawn culture in 2 NA plates separately i.e.Staphylococcus aureus in NA plate 1 and Escheichia coli in NA plate 2. Clostridium perfringens was taken and lawn culture was performed directly in blood plate. Three capillary tubes were taken and a well is cut on the 3 culture plates respectively.

\section{Introduction of prosopisjuliflora extract}

Ten microlitres of the extract from the prosopisjuliflora seeds were taken in culture plates and incubated at 37 degree Celsius for $24 \mathrm{~h}$. It is then introduced into the respective culture plates and the results were observed [7].

\section{RESULTS}

After performing the technique observation was made. It was found that all three microorganisms taken for the research i. e gram positive cocciStaphylococcus aureus, gram negative bacilli Escherichia coli and gram positive bacilli Clostridium perfringesns showed sensitivity to the extracts of prosopisjuliflora seed. The zone of inhibition of aerobic organism was found to be $24 \mathrm{~mm}$ (fig. 1). The zone of inhibition of anaerobic organisms were found to be $18 \mathrm{~mm}$. (fig. 3).

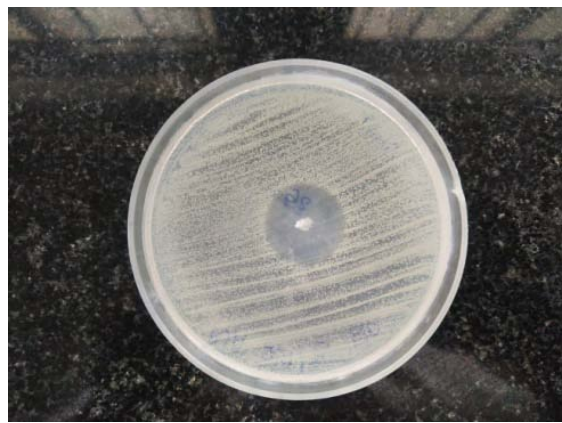

Fig.1: Antibacterial activity of prosopisjuliflora seed extrat against aerobic organisms

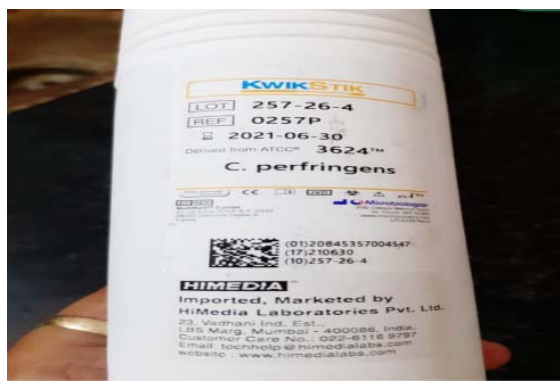

Fig.2:Clostridium perfringens ATCC 3624

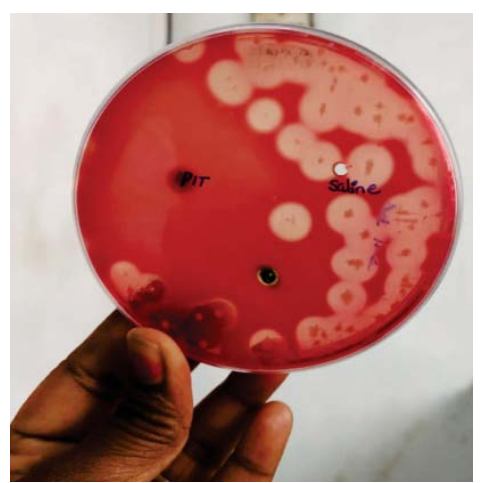

Fig.3: Antibacterial activity of prosopisjuliflora seed extract against clostridium perfringens in blood agar

\section{DISCUSSION}

Prosopisjuliflora seeds contain nutritional compounds and can be considered as an alternate protein source to protein energy malnutrition among the economically weaker people.

Results showed the effectiveness of Prosopisjuliflora seeds against all tested organisms. Gram-positive bacteria were more susceptible than gram negative bacteria. Higher susceptibility of gram-positive bacteria to other extracts has also been reported in some previous investigations. The less susceptibility of gram-negative bacteria to antibacterial substances in such studies may be due to the outer membrane and lipopolysaccharide molecules of gram negative organism which make it difficult for the antimicrobial molecules to enter thus it acts as a barrier and gives protection to the bacteria. Gram-positive bacteria do not have this type of outer membrane and cell wall construction so it may be more susceptible to the extracts of prosopisjuliflora seeds [10].

In the study conducted by Prabhas, juliprosinene and juliflorinine isolated from P. juliflora exhibit antibacterial effects on bacteria such as Escherichiacoli, Staphylococcus aureus, Klebsiella pneumonia, and Shigellasonnei[10].

The study conducted by Singh et al. showed the antibacterial effect of alkaloid rich fractions of Prosopisjulifloraseeds. Different parts of the plants such as leaf, flowers, pods were investigated to find their action on gram positive and gram negative bacteria. The plant material was collected from the Shekhawati regions of Rajasthan, India. According to their study, the leaf extract showed the highest antibacterial properties and seed pod and flower also exhibited slight antibacterial activity with the potential to inhibit antibioticresistant strains. On the contrary, the root and stem extracts did not show zone of inhibition against any of the tested bacteria. In our study, seed pods of Prosopisjuliflora exhibited antibacterial activity. Therefore, our results are in accordance with the results of the study done by Singh et al.[11]

In the study performed by Taheriet al., antibacterial effect of hydroalcoholic extract obtained from the leaf of a species from Chabahar, south east of Iran was investigated. The author found that no antibacterial effect was found in non-heated extract. They also found that the extract showed antibacterial activity after heating by an autoclave. Hence, they supposed that some compounds might cleave by heat and produce new materials with antibacterial properties. However in this study autoclave is not used to find the antibacterial effect. Differences between their results and our results may be due to some factors such as possible dissimilarities in plant species, solvents and the part of plant used for extraction, or geographical regions [12].

\section{CONCLUSION}

The seed extract of Prosopisjuliflora showed antibacterial activity against aerobic gram positive cocciStaphylococcus aureus, gram negative bacilli Escherichia coli and anaerobic gram positive bacilli Clostridiumperfringens. Further investigations onthemodeofactionandrelatedpharmacologicalstudiessuchasclinical trials, drugformulation and invitro investigations are highly recommended. This study shows the antibacterial activity of prosopisjuliflora seed extract against only few organisms. Its activity against other organisms will be dealt in further studies.

\section{ACKNOWLEDGEMENT}

Highly grateful to the mentors, the HOD of the microbiology department, the Dean and the management of the Saveetha Medical College and Hospital for guiding and providing all the facilities to do this research work.

\section{FUNDING}

Nil

\section{AUTHORS CONTRIBUTIONS}

All the authors have contributed equally.

\section{CONFLICT OF INTERESTS}

Declared none 


\section{REFERENCES}

1. Saga T, Yamaguchi K. History of antimicrobial agents and resistant bacteria. Japan Med Assoc J 2009;52:103-8.

2. Farnsworth NR, Akerele O, Bingel AS, Soejarto DD, Guo Z. Medicinal plants in therapy. Bull World Health Organ 1985;63:965-81.

3. Pasiecznik NM, Harris PJC, Smith SJ. Identifying tropical prosopis species: a field guide. Coventry: HDRA Publishing; 2004

4. Gonzalez Lamothe R, Mitchell G, Gattuso M, Diarra MS, Malouin F, Bouarab K. Plant antimicrobial agents and their effects on plant and human pathogens. Int J MolSci 2009;10:3400-19.

5. Sathiya M, Muthuchelian K. Investigation of phytochemical profile and antibacterial potential of ethanolic leaf extract of prosopisjuliflora DC. Ethnobot Leaflets 2008;12:1240-5.

6. Alexander TJL, Gyles CL. Escherichia coli in domestic animals and humans. Wallingford, United Kingdom: CAB International; 1994. p. 151-70.
7. Kiu R, Hall LJ. An update on the human and animal enteric pathogen clostridium perfringens. Emerg Microbes Infect 2018;7:141.

8. Tong SY, Davis JS, Eichenberger E, Holland TL, Fowler VG Jr. Staphylococcus aureus infections: epidemiology, pathophysiology, clinical manifestations, and management. ClinMicrobiol Rev 2015;28:603-61.

9. Tendencia, Eleonor A. Disk diffusion method. SEAFDEC, Aquaculture Department Japan. Chapter 2; 2004. p.14-29.

10. Sathiya M, Muthuchelian K. Investigation of phytochemical profile and antibacterial potential of ethanolic leaf extract of prosopisjuliflora DC. Ethnobot Leaflets 2008;12:1240-5.

11. Singh S. Phytochemical analysis of different parts of prosopisjuliflora.Int J C Pharm Res 2012;4:59-61.

12. Taheri A, Seyfan A, Jalalinezhad S, Nasery F. Study of antibacterial effect of Prosopis sp. hydro-alcoholic extract. Pejouhandeh 2012;17:196-202. 